\title{
Comparison of The Anxiety and Depression Levels of Pregnant Women With COVID-19 and Healthy
}

\section{Pregnant Women}

\author{
Aysegul Bestel ${ }^{1^{*}}$, Aybeniz Civan Kahve ${ }^{2}$, Merve Aldikactioglu Talmac ${ }^{3}$, Pinar Yalcin \\ Bahat $^{1}$, Zübeyde Aytufan $^{1}$, İbrahim Polat ${ }^{3}$, İsmail Özdemir ${ }^{1}$ \\ ${ }^{1}$ University of Health Sciences Istanbul Kanuni Sultan Suleyman Training and Research Hospital, Department of \\ Obstetrics and Gynecology; Halkali, Istanbul, Turkey \\ ${ }^{2}$ University of Health Sciences Ankara City Hospital, Department of Psychiatry; Ankara, Turkey \\ ${ }^{3}$ Başaksehir Cam and Sakura City Hospital, Department of Obstetrics and Gynecology; Başaksebir, Istanbul, Turkey
}

\begin{abstract}
In our study, it was planned to compare the anxiety and depression levels of pregnant women diagnosed with COVID-19, the sociodemographic characteristics that may be associated, and the change in anxiety and depression levels after the disease regressed.

There were a total of 158 participants, including 63 patients and 95 controls participating in the study. The mean age was $28.61+/-6.47$ years. Pregnant women with COVID-19 and recommended follow-up and treatment between May 2020 and August 2020 were included in the study. Sociodemographic data form, Beck Depression Scale, Beck Anxiety Scale, State and Trait Anxiety Scale prepared by researchers were filled with patients who volunteered to participate in the study. The scales indicated were repeated when the patients came to their first check-up after fifteen days from discharge.

There is a statistically significant difference between the COVID-19 diagnostic groups in terms of Anxiety score (p <0.05). While the anxiety level was the highest in the COVID-19 positive diagnosis group (10.38), it was lower in the COVID-19 positive control group (5.7). According to multiple comparison results; There is a difference between the COVID-19 positive diagnosis group and the control and negative groups $(\mathrm{p}<0.05)$.

There is a statistically significant difference between the COVID-19 diagnostic groups in terms of Depression score ( $\mathrm{p}<0.05)$. While the Depression level was highest in the COVID-19 positive diagnosis group (9.51), it was lower in the COVID-19 positive control group (5.8). There is a difference between the COVID-19 positive diagnosis group and the control and negative groups $(\mathrm{p}<0.05)$. There is a difference between the COVID-19 positive diagnosis group and the control group $(\mathrm{p}<0.05)$.

This study showed us that COVID-19 infection increases anxiety and depression in pregnant women, and anxiety and depression are highest at the first diagnosis of the disease, especially in pregnant women with COVID-19.
\end{abstract}

Keywords: COVID-19, coronavirus, pregnancy, depression, anxiety, pandemic, stress

\section{Introduction}

Coronavirus Disease 2019 (COVID-19) has spread all over the world rapidly and caused a pandemic in a few month after being identified as the cause of prevalent pneumonia cases in Wuhan, China in December 2019. (1,2). After its identification in Wuhan, China, in December 2019, more than 1,000,000 people have tested positive and are confirmatory in just 4 months all over the world (3).

It was declared as a global epidemic (Pandemic) by the World Health Organization (WHO) on March 11, 2020, after the virus was seen in countries other than China and spread more than two months after the epidemic (4). The first case in our country was seen on March 11, and the measures taken from this date have been tightened (5).

The curfew, quarantine and isolation measures imposed in the COVID-19 pandemic are new to many and may raise concerns about how people react individually and collectively. However, previous studies have shown that symptoms such as loneliness, increase in anxiety, increase in depressive symptoms and insomnia occur during this period in general population $(2,6,7)$.

Psychiatric illnesses and emotional breakdowns associated with COVID-19 are expected to increase due to uncertainty about the prognosis and treatment of the disease, personal freedoms, and financial conditions (6). Since pregnant

*Corresponding Author: Aysegul Bestel, Turgut Ozal Street Atakent District Number:1 Kanuni Sultan Suleyman Training and Research Hospital Halkali/Istanbul Zip Code 34303

E-mail: draysegulciftci@gmail.com, Phone: +90 (539) 2501802

ORCID ID: Aysegul Bestel: 0000-0002-0700-6400, Aybeniz Civan Kahve: 0000-0002-0683-5207, Merve Aldikactioglu Talmac: 00000001-7219-1772, Pinar Yalcin Bahat: 0000-0003-2558-1924, Zübeyde Aytufan: 0000-0002-4015-865X, İbrahim Polat: 0000-0002-1418634X, İsmail Özdemir: 0000-0002-9043-1431

Received: 25.01.2021, Accepted: 04.06.2021 
women encounter these unfavorable conditions in prenatal period more because of the pandemic, the comorbidity rates of anxiety and depressive disorders are high. However, the exact prevalence of this comorbidity is not well known (8). While it has been reported that there are mental disturbances in samples of community and healthcare workers, studies about how pregnant women are affected mentally in this process are limited. It has been reported in previous studies that COVID-19 will have effects on pregnant women.

Depression may occur during pregnancy, or the existing depression may be exacerbated because it is a time of physical and emotional weakness (9). Due to the increased susceptibility to depression during pregnancy, it can be thought that the possibility of depression will increase in patients with extra pregnancy-related risk factors. In the presence of depression, risky situations may occur in terms of pregnancy and fetus health. It has been reported in previous studies that mental illnesses such as depression and anxiety cause preeclampsia, increase in preterm birth and decrease in birth weight and Apgar score in pregnant women, therefore it is important to recognize and treat them (10).

In this study, we aimed to investigate the psychological effects of COVID-19 on pregnant women. We believe that the data of our study will be a guide in performing therapeutic interventions with a holistic approach in the follow-up of pregnant women. This study aimed to investigate the relationship between COVID-19 infection and increased anxiety and depression during pregnancy.

\section{Materials and Methods}

The study protocol was approved by the institution's Ethics Committee (2020.04.22-1474). Written and verbal informed consent was obtained from all the participant before their enrollment in the study.

Procedure: This study is a cross-sectional study in which the scales were applied face-to-face to evaluate and compare the state and trait anxiety, and depression levels of pregnant women who had COVID-19 and those who did not have COVID19 during the pandemic period. The researchers' sociodemographic data form, State-Trait Anxiety Scale (STAI), Beck Depression Inventory (BDI), and Beck Anxiety Inventory (BAI) were applied to pregnant women with and without COVID.
Sample: Our study included pregnant women who were admitted to the tertiary referral hospital emergency department or outpatient clinic between May 2020- August 2020. Patient group were followed up and treated with the diagnosis of COVID-19. Control group were pregnant women without COVID-19 who came for routine pregnancy examination and they did not have comorbid disease.

A total of 183 pregnant women who could read and write in Turkish were interviewed in the study. Six patients could not come to the control 15 days later, 10 patients had existing obstetric problems and nine patients have serious mental illnesses (psychotic disorder/intellectual disability), so they were excluded from the study. Finally 158 patients (63 patients with COVID-19 and 95 controls) were included in the study. Patients with COVID-19 symptoms (fever, cough, sore throat, common muscle pain) and positive PCR test were in the patient group. COVID-19 PCR test positive patients were evaluated on the day of hospitalization and on the $15^{\text {th }}$ days after discharge from the hospital.

\section{Data Collection Tools}

Sociodemographic data form: A sociodemographic form was created by researchers and included the following information about the participants: age, marital status, number of children, who is the caregiver, whether to support children with care after childbirth (one of the family or a paid assistant/carer), whether there is a person over 65 years old at home, whether there is a person with a chronic disease at home, educational status (years), working status, pregnancy number, pregnancy week, family income level, whether alcohol or substance use, whether or not a previous psychiatric treatment history, whether there is antidepressant treatment before, whether there is a family history of psychiatric illness.

Beck Depression Inventory: The aim of Beck Depression Inventory is to reveal the existence of mood of depression and seriousness of the depression situation. Beck Depression Inventory was developed by Beck et al. (11) and Hisli et al conducted the reliability and validity studies (12).

The BDI consists of a 21 -item questionnaire that assesses affective symptoms of depression, including hopelessness, irritability, feelings of guilt, pessimism, worthlessness, self-dislike, and suicidal thoughts as somatic symptoms such as loss of appetite, fatigue, difficulties sleeping and concentrating. The answer to each question was 
scored on a scaled value of 0 to 3 , and the total score determined the severity of depression: 0-13 indicating minimal depression; 14-19 indicating mild depression; 20-28 indicating moderate depression; 29-63 indicating severe depression (13). The highest score to be received is 63 . The height of the total score indicates the severity of depression.

Beck Anxiety Inventory: It was aimed to evaluate levels of anxiety in participants. This instrument has been translated into Turkish, validated through back-translation and test-retest reliability (14).

It has 21 items which measures the common symptoms of clinical anxiety, such as fear of irritability and loss of control, shows how disturbed each symptom by each symptom. Each symptom is rated to show how disturbed they are on a 4-point scale ranging from 0 (not at all) to 3 (I could not bear it seriously), and total scores range from 0 to 63 . A score of 63 indicates the highest level of anxiety. A score of 10 indicates mild anxiety, while 19 reflects moderate anxiety. It evaluates physiological symptoms (13 items), cognitive aspects (5 items), and both somatic and cognitive symptoms (3 items) are represented (15).

State-Trait Anxiety Inventory (STAI): It was developed by Spielberger et al. and used to measure the anxiety levels of the patients. Translation into Turkish, reliability, and validity studies was conducted by Le Compte and Öner (16). The scale, which is a self-assessment type, contains 40 items consisting of short expressions. It is filled by 1 to 4 points by the participants. The scale is consisted from two parts, the "state anxiety form" created to determine what was felt before the competition and the 20-item "trait anxiety form" created to determine what has been felt for the last seven days (17).

Statistical Analysis: The data were analyzed with SPSS 25 program. Kolmogorov-Smirnov test was employed for assessing the normality of distribution of data together with skewness, kurtosis values and histogram. For comparing the categories, chi-square test was implemented. Pearson correlation

coefficient was used for evaluating the correlation of normally distributed data. Correlation coefficient power levels; $0,0<\mathrm{r}<0.25$ too weak, $0.26<\mathrm{r}<0.49$ weak, $0.50<\mathrm{r}<0.69$ medium, 0.70 $<\mathrm{r}<0.89$ strong, $0.90<\mathrm{r}<1.0$ strong (18).

In order to compare the average values of the two independent groups having normal distribution pattern, Independent Samples T-Test was performed. And in dependent groups, Dependent Group $T$ Test was used to compare the continuous variable. For comparing the median values of other two independent groups which does not follow normal distribution, Mann Whitney U test was applied. One Way ANOVA test was implemented to compare the 3 groups whose data was distributed normally. In independent groups, if the distribution of variants is not homogeneous (Levene's p <, 05), Welch statistics were used. If a significant difference is observed between the groups, Bonferroni correction was applied to detect the difference. In order to identify the causes of changes on anxiety and depression levels, logistic regression was carried out. If $\mathrm{p}<0.05$, it was accepted as significant.

\section{Results}

There were a total of 158 participants, including 63 patients and 95 controls participating in the study. The mean age was $28.61 \pm 6.47$ years. Most of the patients $(34.9 \%$ in pregnant women with COVID-19; $36 \%$ of the control group) are 31 years old and above. In Table 1, the comparison of patients and the controls in terms of all sociodemographic data is given.

Patients have a higher rate of psychiatric disease $(22.2 \%)$ and the use of antidepressants (19.0\%) than controls (respectively $\mathrm{p}<0.001, \mathrm{p}: 0.013)$ (Table 2).

There is a positive correlation between the State Anxiety score $(\mathrm{p}<0.001, \mathrm{r}: 0.640)$ and the Trait Anxiety $(\mathrm{p}<0.001, \mathrm{r}: 0.584)$, total anxiety $(\mathrm{p}<0.001$, $\mathrm{r}: 0.654)$ scores in pregnants with COVID-19)

There is no statistically significant difference between the patients admission and the 15th day controls in terms of State Anxiety scores $(\mathrm{p}=0.106)$.

In the COVID-19 positive group, there is a statistically significant difference between the diagnosis Trait Anxiety score and the control Trait Anxiety score $(\mathrm{p}=0.009)$. Trait Anxiety level at the time of control is lower (35.64) (Table 6).

There is no statistically significant difference between the COVID-19 negative group and the COVID-19 positive group in State Anxiety, Trait Anxiety, and Total Anxiety scores ( $p=0.951$; $\mathrm{p}=0.391 ; \mathrm{p}=0.101)$ (Table 4) (Table 5).

There is a statistically significant difference between the COVID-19 negative group and the COVID-19 positive group in terms of Depression scores $(p=0.015)$ (Table 3$)$. Depression level is 
Table 1. Comparison of Patients With COVID-19 and The Control Group In Terms of Sociodemographic Characteristics

\begin{tabular}{|c|c|c|c|c|c|}
\hline & & $\begin{array}{c}\text { Patients with COVID-19 } \\
\mathrm{n}(\%)\end{array}$ & $\begin{array}{c}\text { Controls } \\
\mathrm{n}(\%)\end{array}$ & $\mathrm{X} 2$ & $\mathrm{p}^{*}$ \\
\hline \multirow{4}{*}{ Age } & 20 and below & $9(14.3)$ & $4(4.2)$ & \multirow{4}{*}{5.015} & \multirow{4}{*}{0.171} \\
\hline & $21-25$ & $17(27)$ & $29(30.5)$ & & \\
\hline & $26-30$ & $15(23.8)$ & $26(27.4)$ & & \\
\hline & 31 and older & $22(34.9)$ & $36(37.9)$ & & \\
\hline \multirow{3}{*}{ Marital Status } & Single & $1(1.6)$ & $2(2.1)$ & \multirow{2}{*}{$\mathrm{x}$} & \multirow{3}{*}{0.999} \\
\hline & Married & $62(98.4)$ & 93 (97.9) & & \\
\hline & No & $24(38.1)$ & $34(35.8)$ & \multirow{4}{*}{11.605} & \\
\hline \multirow{3}{*}{$\begin{array}{l}\text { Number of Children } \\
\text { She Has }\end{array}$} & 1 & $11(17.5)$ & $38(40)$ & & \multirow{3}{*}{0.009} \\
\hline & 2 & $15(23.8)$ & $11(11.6)$ & & \\
\hline & 3 and above & $13(20.6)$ & $12(12.6)$ & & \\
\hline \multirow{5}{*}{ Education status } & İlliterate & $6(9.7)$ & $3(3.2)$ & \multirow{5}{*}{$\mathrm{x}$} & \multirow{5}{*}{0.076} \\
\hline & Primary School & $18(29)$ & $29(30.5)$ & & \\
\hline & Middle School & $21(33.9)$ & $21(22.1)$ & & \\
\hline & High School & $13(21)$ & $26(27.4)$ & & \\
\hline & University & $4(6.5)$ & $16(16.8)$ & & \\
\hline \multirow{2}{*}{ Working status } & Housewife & $55(87.3)$ & 77 (81.1) & \multirow{2}{*}{0.669} & \multirow{2}{*}{0.413} \\
\hline & & $8(12.7)$ & $18(18.9)$ & & \\
\hline \multirow{4}{*}{ Income rate } & $1500 \mathrm{TL}<$ & $8(12.7)$ & $20(21.1)$ & \multirow{4}{*}{$\mathrm{x}$} & \multirow{4}{*}{0.496} \\
\hline & $1500-3000 \mathrm{TL}$ & $37(58.7)$ & $54(56.8)$ & & \\
\hline & $3000-4500 \mathrm{TL}$ & $14(22.2)$ & $15(15.8)$ & & \\
\hline & $4500 \mathrm{TL}>$ & $4(6.3)$ & $6(6.3)$ & & \\
\hline \multirow{2}{*}{$\begin{array}{l}\text { Having a child under } \\
\text { the age of } 12\end{array}$} & No & $26(41.3)$ & $46(48.4)$ & \multirow[b]{2}{*}{0.781} & \multirow[b]{2}{*}{0.377} \\
\hline & Yes & $37(58.7)$ & $49(51.6)$ & & \\
\hline \multirow{2}{*}{$\begin{array}{l}\text { Childcare under the age } \\
\text { of } 12\end{array}$} & No & $24(64.9)$ & $31(63.3)$ & \multirow{2}{*}{0.001} & \multirow{2}{*}{0.999} \\
\hline & Yes & $13(35.1)$ & $18(36.7)$ & & \\
\hline \multirow{2}{*}{ Postpartum care } & No help & $42(66.7)$ & 78 (82.1) & \multirow{2}{*}{4.134} & \multirow{2}{*}{0.042} \\
\hline & Family will help & $21(33.3)$ & $17(17.9)$ & & \\
\hline \multirow{2}{*}{ Old age at home } & No & $50(79.4)$ & $84(88.4)$ & \multirow{2}{*}{1.760} & \multirow{2}{*}{0.185} \\
\hline & Yes & $13(20.6)$ & $11(11.6)$ & & \\
\hline A person with chronic & No & $48(76.2)$ & $88(92.6)$ & 7227 & 0007 \\
\hline illness at home & Yes & $15(23.8)$ & $7(7.4)$ & 7.227 & $0.00 /$ \\
\hline
\end{tabular}

*The level of statistical significance is set at $\mathrm{p}<0.05$, Chi-squared test. $\mathrm{x}$ :Fisher Exact; n:number of people; $\%$ :percentage

higher in the COVID-19 positive group (9.51) (table 7).

When multivariate ANOVA results were examined, there was no statistically significant variable in the model established to determine the factors affecting anxiety and depression.

While the anxiety and depression level was the highest in the COVID-19 positive diagnosis group (10.38 and 9.51), it was lower in the COVID-19 positive control group (5.7 and 5.8). According to multiple comparison results; There is a difference between the patients with COVID-19 group and the patients with COVID-19 control group and negative groups $(\mathrm{p}=0.03)$ (Table 8$)$.

\section{Discussion}

The COVID-19 pandemic is an infection that rapidly affects the whole world and causes many people's death, and requires social isolation due to 
Table 2. Comparison of Patients With Covid-19 And Controls In Terms of Psychiatric Disease History

\begin{tabular}{|c|c|c|c|c|c|}
\hline & & $\begin{array}{c}\text { Patients with } \\
\text { COVID-19 } \\
\text { n }(\%)\end{array}$ & $\begin{array}{l}\text { Controls } \\
\text { n }(\%)\end{array}$ & $\mathrm{X} 2$ & $\mathrm{p}^{*}$ \\
\hline \multirow{2}{*}{$\begin{array}{l}\text { History of psychiatric } \\
\text { disorders }\end{array}$} & $\mathrm{No}$ & $49(77.8)$ & $92(96.8)$ & \multirow{2}{*}{12.421} & \multirow{2}{*}{$<0.001$} \\
\hline & Yes & $14(22.2)$ & $3(3.2)$ & & \\
\hline \multirow{5}{*}{$\begin{array}{l}\text { Type of psychiatric } \\
\text { disorders }\end{array}$} & Depression & $6(42.9)$ & $2(50)$ & \multirow{5}{*}{$\mathrm{x}$} & \multirow{5}{*}{0.999} \\
\hline & Anxiety & $4(28.6)$ & $1(25)$ & & \\
\hline & Psychotic disorder & $0(0)$ & $0(0)$ & & \\
\hline & Bipolar disorder & $1(7.1)$ & $0(0)$ & & \\
\hline & Panic attacks & $3(21.4)$ & $1(25)$ & & \\
\hline \multirow{2}{*}{$\begin{array}{l}\text { Use of antidepressant } \\
\text { medication }\end{array}$} & No & $51(81)$ & $90(94.7)$ & \multirow{2}{*}{6.129} & \multirow{2}{*}{0.013} \\
\hline & Yes & $12(19)$ & $5(5.3)$ & & \\
\hline \multirow{2}{*}{$\begin{array}{l}\text { Use of antidepressant } \\
\text { medication in family }\end{array}$} & No & $56(88.9)$ & $91(95.8)$ & \multirow{2}{*}{$\mathrm{x}$} & \multirow{2}{*}{0.116} \\
\hline & Yes & $7(11.1)$ & $4(4.2)$ & & \\
\hline \multirow{2}{*}{ Additional disease } & No & $62(98.4)$ & $95(100)$ & \multirow{2}{*}{$\mathrm{x}$} & \multirow{2}{*}{0.399} \\
\hline & Yes & $1(1.6)$ & $0(0)$ & & \\
\hline
\end{tabular}

* The level of statistical significance is set at $\mathrm{p}<0.05$; Chi-squared test, $\mathrm{x}$ : Fisher Exact; n: number of people; \%: percentage

Table 3. Comparison of pregnant women with COVID 19 and the control group in terms of depression and anxiety levels

\begin{tabular}{|c|c|c|c|c|}
\hline & & $\begin{array}{c}\text { Patients with } \\
\text { COVID-19 } \\
\text { n }(\%)\end{array}$ & $\begin{array}{l}\text { Controls } \\
\mathrm{n}(\%)\end{array}$ & $\mathrm{p}^{*}$ \\
\hline \multirow{4}{*}{ STAI** } & Absent & $35(55.6)$ & $63(66.3)$ & \multirow{4}{*}{0.207} \\
\hline & Mild & $14(22.2)$ & $20(21.1)$ & \\
\hline & Moderate & $13(20.6)$ & $9(9.5)$ & \\
\hline & Severe & $1(1.6)$ & $3(3.2)$ & \\
\hline \multirow{4}{*}{$\mathrm{BDI}^{* * *}$} & Absent & $35(55.6)$ & $70(73.7)$ & \multirow{4}{*}{0.065} \\
\hline & Mild & $17(27)$ & $15(15.8)$ & \\
\hline & Moderate & $10(15.9)$ & $10(10.5)$ & \\
\hline & Severe & $1(1.6)$ & $0(0)$ & \\
\hline
\end{tabular}

*: The level of statistical significance is set at $\mathrm{p}<0.05$; Chi-squared test $* *$ : State-Trait Anxiety Inventory; $* * * B e c k$ Depression Inventory; n: number of people; \%: percentage

its transmission from person to person by the respiratory route. With the increase in fear and stress levels worldwide, pregnant women are also worried about their own health and the fetus's health.

In our study, to compare depression and anxiety in pregnant women with and without COVID-19 infection, patients with positive COVID-19 PCR tests and patients without COVID-19 suspicion were evaluated for depression, anxiety, state, and trait anxiety.

In patients with COVID-19, the level of state anxiety and continuity anxiety were significantly higher at the time of diagnosis than when they came for control. There is a significant relationship between state anxiety and trait anxiety and anxiety and depression in the patients with COVID-19.

In patients with COVID-19, the level of anxiety and depression was significantly higher at the time of diagnosis than when they came for control. This can be interpreted as the presence of COVID-19 symptoms, especially in patients who show improvement or decrease uncertainty about the disease. 
Bestel et al / Psychological Effects of COVID-19 in Pregnant Women

Table 4. Anxiety and Depression Levels of Patients With COVID-19 and Controls

\begin{tabular}{|c|c|c|c|c|c|c|}
\hline & \multicolumn{2}{|c|}{$\begin{array}{l}\text { Patients with } \\
\text { COVID-19 }\end{array}$} & \multicolumn{2}{|c|}{$\begin{array}{l}\text { Patients with } \\
\text { COVID-19 (15th day) }\end{array}$} & \multicolumn{2}{|l|}{ Controls } \\
\hline & Min-Max & Mean \pm SD & Min-Max & Meant SD & Min-Max & Mean \pm SD* \\
\hline $\begin{array}{l}\text { State Anxiety } \\
\text { Scores }\end{array}$ & $19-62$ & $37.65 \pm 11.66$ & $20-57$ & $34.88 \pm 9.16$ & $20-66$ & $37.76 \pm 9.99$ \\
\hline $\begin{array}{l}\text { Trait Anxiety } \\
\text { Scores }\end{array}$ & $20-64$ & $39.35 \pm 10.42$ & $23-50$ & $35.66 \pm 7.35$ & $15-69$ & $37.99 \pm 9.25$ \\
\hline $\begin{array}{l}\text { Total Anxiety } \\
\text { Scores }\end{array}$ & $0-34$ & $10.38 \pm 8.08$ & $0-19$ & $5.7 \pm 5.2$ & $0-31$ & $8.33 \pm 7.38$ \\
\hline $\begin{array}{l}\text { Beck Depression } \\
\text { Scores }\end{array}$ & $0-32$ & $9.51 \pm 7.3$ & $0-18$ & $5.8 \pm 3.93$ & $0-21$ & $6.91 \pm 5.88$ \\
\hline
\end{tabular}

Table 5. Comparison of Anxiety And Depression Levels of Pregnant Women With COVID-19 and Controls

\begin{tabular}{|c|c|c|c|c|c|c|c|c|}
\hline & \multicolumn{4}{|c|}{$\begin{array}{l}\text { Patients with } \\
\text { COVID-19 }\end{array}$} & \multicolumn{4}{|c|}{ Controls } \\
\hline \multirow{5}{*}{ State Anxiety (1) } & 1 & 2 & 3 & 4 & 1 & 2 & 3 & 4 \\
\hline & 1 & $.623 * *$ & $.513^{* *}$ & $.640 * *$ & 1 & $.320 * *$ & $.386 * *$ & $.375^{* *}$ \\
\hline & & 0.000 & 0.000 & 0.000 & & 0.002 & 0.000 & 0.000 \\
\hline & 63 & 63 & 63 & 63 & 95 & 95 & 95 & 95 \\
\hline & & 1 & $.454 * *$ & $.584 * *$ & & 1 & $.232 *$ & $.283^{* *}$ \\
\hline \multirow[t]{3}{*}{ Trait Anxiety (2) } & & & 0.000 & 0.000 & & & 0.024 & 0.006 \\
\hline & & 63 & 63 & 63 & & 95 & 95 & 95 \\
\hline & & & 1 & $.694 * *$ & & & 1 & $.650 * *$ \\
\hline \multirow[t]{3}{*}{ Total Anxiety (3) } & & & & 0.000 & & & & 0.000 \\
\hline & & & 63 & 63 & & & 95 & 95 \\
\hline & & & & 1 & & & & 1 \\
\hline
\end{tabular}

Depression(4)

63

95

*The level of statistical significance is set at $\mathrm{p}<0.05$; ${ }^{*}$ The level of statistical significance is set at $\mathrm{p}<0.01$ in Pearson Correlation

Table 6. Comparison of Anxiety and Depression Levels According To Examination Date In Patients With COVID-19

\begin{tabular}{lcccc}
\hline & & Mean \pm SD* & $\mathrm{t}$ & $\mathrm{p}^{* *}$ \\
\hline \multirow{2}{*}{ State Anxiety } & Time of first diagnosis & $37.38 \pm 11.25$ & \multirow{2}{*}{0} & 0.106 \\
& In control & $35.26 \pm 9.28$ & & \\
Trait Anxiety & Time of first diagnosis & $38.64 \pm 9.96$ & \multirow{2}{*}{2.723} & $0.009^{*}$ \\
& In control & $35.64 \pm 7.16$ & & \\
Total Anxiety & Time of first diagnosis & $9.62 \pm 7.82$ & \multirow{2}{*}{3.146} & $0.003^{*}$ \\
& In control & $6.14 \pm 5.64$ & & \\
Depression & Time of first diagnosis & $9.42 \pm 7.71$ & 3.592 & $0.001^{*}$ \\
\hline
\end{tabular}

*: Standard deviation; ** The level of statistical significance is set at $\mathrm{p}<0.05$; Dependent Groups T Test;

In patients with COVID-19, Beck Depression Inventory score used in the evaluation of depression was higher at the time of diagnosis than when they came for control. Depression value is higher in these patients compared to patients not diagnosed with COVID-19. Likewise, the highest anxiety levels were observed in patients who were positive for COVID-19 at the time of diagnosis, when they came for control later. The lowest anxiety level was observed in 
Table 7. Comparison of Patients With COVID-19 and controls according to anxiety. Depression levels

\begin{tabular}{|c|c|c|c|c|}
\hline & & Mean $\pm \mathrm{SD}$ & $\mathrm{t}$ & $\mathrm{p}^{*}$ \\
\hline State Anxiety & $\begin{array}{c}\text { Patients with COVID-19 } \\
\text { Controls }\end{array}$ & $\begin{array}{c}37.65 \pm 11.66 \\
37.76 \pm 9.99\end{array}$ & -0.062 & 0.951 \\
\hline Trait Anxiety & $\begin{array}{c}\text { Patients with COVID-19 } \\
\text { Controls }\end{array}$ & $\begin{array}{c}39.35 \pm 10.42 \\
37.99 \pm 9.25\end{array}$ & 0.860 & 0.391 \\
\hline Total Anxiety & $\begin{array}{c}\text { Patients with COVID-19 } \\
\text { Controls }\end{array}$ & $\begin{array}{l}10.38 \pm 8.08 \\
8.33 \pm 7.38\end{array}$ & 1.650 & 0.101 \\
\hline Depression & $\begin{array}{c}\text { Patients with COVID-19 } \\
\text { Controls }\end{array}$ & $\begin{array}{l}9.51 \pm 7.3 \\
6.91 \pm 5.88\end{array}$ & 2.471 & $0.015^{*}$ \\
\hline
\end{tabular}

* The level of statistical significance is set at $\mathrm{p}<0.05$. Independent Groups T Test

Table 8. Comparison of Depression and Anxiety Levels According To Examination Date In Patients With COVID-19 and Controls

\begin{tabular}{|c|c|c|c|c|c|c|}
\hline & $\begin{array}{l}\text { (a) } \\
\text { Patients with } \\
\text { COVID-19 } \\
\text { First diagnosis }\end{array}$ & $\begin{array}{l}\text { (b) } \\
\text { Patients with COVID-19 } \\
\text { (Control examination) }\end{array}$ & $\begin{array}{c}\text { (c) } \\
\text { Controls }\end{array}$ & & & \\
\hline & Mean \pm SD & Mean $\pm S D$ & Mean \pm SD & $\mathrm{F}$ & $\mathrm{p}^{*}$ & $\begin{array}{l}\text { Post } \\
\text { Hoc }\end{array}$ \\
\hline $\begin{array}{l}\text { State } \\
\text { Anxiety }\end{array}$ & $37.65 \pm 11.66$ & $34.88 \pm 9.16$ & $37.76 \pm 9.99$ & 1.429 & 0.242 & $\mathrm{x}$ \\
\hline $\begin{array}{l}\text { Trait } \\
\text { Anxiety }\end{array}$ & $39.35 \pm 10.42$ & $35.66 \pm 7.35$ & $37.99 \pm 9.25$ & 2.254 & 0.108 & $\mathrm{x}$ \\
\hline $\begin{array}{l}\text { Total } \\
\text { Anxiety }\end{array}$ & $10.38 \pm 8.08$ & $5.7 \pm 5.2$ & $8.33 \pm 7.38$ & 5.971 & $0.003^{*}$ & $\begin{array}{l}a-b \\
a-c \\
b-c\end{array}$ \\
\hline Depression & $9.51 \pm 7.3$ & $5.8 \pm 3.93$ & $6.91 \pm 5.88$ & 6.042 & $0.003 *$ & $a-b$ \\
\hline
\end{tabular}

*The level of statistical significance is set at $\mathrm{p}<0.05$; One way ANOVA test. Post Hoc: Tamhane (variances are not homogeneous)

patients not diagnosed with COVID-19. Depression and anxiety decreased in pregnant women diagnosed with the disease, depending on the diagnosis and treatment course, but remained at higher levels compared to negative patients.

In previous studies, risk factors were examined and it was found that women are at high risk if their education level is low, family income is low, and physical exercise is less (19). When we examined sociodemographic variables and anxiety and depression in our study, we found no significant difference. This may suggest that the participants' increased anxiety and depression are due to the depression and anxiety-enhancing effect of COVID infection, regardless of risk factors.

The effect of COVID-19 infection on depression and anxiety levels in all pregnant participants was examined by Lebel et al. and an increase was found (20). It is thought that this increase may be due to the uncertainty of the clinical course and treatment of COVID-19 infection in the community and the concern about the poor prognosis of the patients. In our study, it was observed that depression and anxiety increased in patients without COVID-19 infection. However, our study was compared with pregnant women diagnosed with COVID-19, and it was observed that the levels of depression and anxiety were higher in pregnant women diagnosed with COVID-19. This increase may be due especially to early or future pregnancy and the concern of affecting the fetus.

In the literature, especially before and after the pandemic was stated, the anxiety level was examined, and an increase in anxiety and depression symptoms was observed afterward (19). Since we evaluated all patients after the pandemic announcement in our study, the depression level was high even if the patients did not have COVID-19 infection. Like the literature, this result can be explained by observing 
increasing depression scores, especially in social isolation (21).

While the pregnancy period itself is a stress factor for the person, it can be expected that the symptoms of depression will increase when the person is exposed to an extra factor such as a pandemic. Similarly, an increase in anxiety was observed in the study conducted by Preis et al. It is suggested that some therapies may reduce anxiety to increase self-efficacy and motivate women to live a healthy life (22).

In terms of our study's limitations, it may be considered that due to the small number of patients and the insufficient data on COVID-19 infection in the literature, not having sufficient information. Patients with a history of depression and psychiatric illness were included. In order to compare patients with and without psychiatric diseases, further studies should be conducted with a higher number of patients.

Our study is unique in the literature regarding the anxiety and depression course of pregnant patients with COVID-19. Therefore, it sheds light on the literature regarding the necessary approach to pregnant patients, especially in terms of anxiety and depression tendency they experience due to COVID-19.

\section{References}

1. Rasmussen SA, Smulian JC, Lednicky JA, Wen TS, Jamieson DJ. Coronavirus Disease 2019 (COVID-19) and Pregnancy: What obstetricians need to know. American journal of obstetrics and gynecology. 2020.

2. Huang J-w, Zhou X-y, Lu S-j, Xu Y, Hu J-b, Huang M-l, et al. Dialectical behavior therapybased psychological intervention for woman in late pregnancy and early postpartum suffering from COVID-19: a case report. Journal of Zhejiang University Science B. 2020:1-6.

3. Dotters-Katz SK, Hughes BL. Considerations for obstetric care during the COVID-19 pandemic. American journal of perinatology 2020; 37: 773 .

4. Organization WH, Organization WH. Pneumonia of unknown cause-China', Emergencies preparedness, response. Disease outbreak news, World Health Organization (WHO). 2020.

5. Şenol c, bilsel a. Türkiye'de covid-19 (coronavirüs) pandemisinin durumu ve algoritmik hesaplamaya göre gelecekteki durum analizi.
6. Pfefferbaum B, North CS. Mental health and the Covid-19 pandemic. New England Journal of Medicine. 2020.

7. Salari N, Hosseinian-Far A, Jalali R, VaisiRaygani A, Rasoulpoor S, Mohammadi M, et al. Prevalence of stress, anxiety, depression among the general population during the COVID-19 pandemic: a systematic review and meta-analysis. Globalization and health 2020; 16: 1-11.

8. Falah-Hassani K, Shiri R, Dennis C-L. The prevalence of antenatal and postnatal comorbid anxiety and depression: a metaanalysis. Psychological medicine. 2017; 47: 2041.

9. Galbally M, Snellen M. Providing the evidence for managing depression in pregnancy. Pediatrics 2020; 145 (5).

10. Alder J, Fink N, Bitzer J, Hösli I, Holzgreve W. Depression and anxiety during pregnancy: a risk factor for obstetric, fetal and neonatal outcome? A critical review of the literature. The Journal of Maternal-Fetal \& Neonatal Medicine 2007; 20: 189-209.

11. Beck AT. Cognitive therapy of depression: Guilford press; 1979.

12. Hisli N. Beck depresyon envanterinin universite ogrencileri icin gecerliligi, guvenilirligi.(A reliability and validity study of Beck Depression Inventory in a university student sample). J Psychol 1989; 7: 3-13.

13. Kanmogne GD, Qiu F, Ntone FE, Fonsah JY, Njamnshi DM, Kuate CT, et al. Depressive symptoms in $\mathrm{HIV}$-infected and seronegative control subjects in Cameroon: Effect of age, education and gender. PloS one 2017; 12: e0171956.

14. Ulusoy M, Sahin NH, Erkmen H. The Beck anxiety inventory: psychometric properties. J Cogn Psychother 1998; 12: 163-172.

15. Beck AT, Steer RA, Carbin MG. Psychometric properties of the Beck Depression Inventory: Twenty-five years of evaluation. Clinical psychology review 1988; 8: 77-100.

16. Öner N, Le Compte vA. State-trait anxiety inventory handbook. Bogazici University, Istanbul, Turkey. 1985.

17. Civan A, Özdemir İ, Taş İ, Çelik A. Bedensel engelli ve engelli olmayan tenis sporcularinın durumluk ve sürekli kayg1 düzeylerinin karşılaştırılması. Selçuk Üniversitesi Beden Eğitimi ve Spor Bilim Dergisi 2012; 14: 83-87.

18. Akgül A, Çevik O. İstatistiksel Analiz Teknikleri, Emek Ofset Ltd. Şti Ankara. 2003.

19. Wu Y, Zhang C, Liu H, Duan C, Li C, Fan J, et al. Perinatal depressive and anxiety symptoms of pregnant women along with COVID-19 outbreak in China. American Journal of Obstetrics and Gynecology. 2020. 
Bestel et al / Psychological Effects of COVID-19 in Pregnant Women

20. Lebel C, MacKinnon A, Bagshawe M, Tomfohr-Madsen L, Giesbrecht G. Elevated depression and anxiety among pregnant individuals during the COVID-19 pandemic. 2020.

21. Durankuş F, Aksu E. Effects of the COVID19 pandemic on anxiety and depressive symptoms in pregnant women: a preliminary study. The Journal of Maternal-Fetal \& Neonatal Medicine 2020; 1-7.

22. Preis H, Mahaffey B, Heiselman C, Lobel M. Pandemic-related pregnancy stress and anxiety among women pregnant during the coronavirus disease 2019 pandemic. American Journal of Obstetrics \& Gynecology MFM 2020; 2: 100155.

East J Med Volume:27, Number:1, January-March/2022 